few minutes later. The reproduced pictures were in all cases of high quality, and it is clear that this new British system has materially advanced the technique of television and will have important applications. No difficulty is foreseen in extending the technique to colour television when this is brought into service. In the meantime, following these very successful demonstrations, one of these equipments is to be taken into use in the B.B.C. television studios for trial during normal programme transmissions, and some viewers may have already witnessed its inclusion in a recent 'Panorama' programme.

\title{
OBITUARIES
}

\section{Lieut.-Colonel Mervyn O'Gorman, C.B.}

Mervyn O'Gorman, who died on March 16 at the age of eighty-six, should be recognized as one of the great pioneers of the application of science to aeronautics, but there are few now left who remember his outstanding work during 1909-16. In 1909 there was practically no science of aeronautics; no scientific principles of design; and there were no reliable British aircraft engines. Executive officers in high positions had no conviction that aeroplanes would ever be of real military value. But Haldane, who was then Secretary of State for War, made up his mind that "science should come first". He set up the Advisory Committee for Aeronautics, with Lord Rayleigh as chairman. His next step was to offer a part-time appointment as superintendent of the existing Army Balloon Factory to O'Gorman, who was by then a well-known consulting engineer, and a partner in the firm of Swinburne, O'Gorman and Baillie. Haldane made him a member of the Advisory Committee, directing him to act on their advice, and also gave him the right of direct access to himself. O'Gorman was directly responsible to the Master General of Ordnance, Sir Charles Hadden, who was also made a member of the Advisory Committee, where he came into contact with some of the most distinguished scientific men of the day. Hadden got infected with the scientific spirit, and became a warm supporter of O'Gorman in his endeavour to promote large-scale experimental work at Farnborough on aeroplanes and engines in order to supplement and extend the experiments on models at the National Physical Laboratory. So everything went swim. mingly at first. The Balloon Factory was soon changed out of all recognition; it became the Army Aircraft Factory in 1911, and the Royal Aircraft Factory in 1912. The numbers employed rose from the original 100 to 2,000 at the beginning of the First World War in 1914. O'Gorman soon gathered around him an exceptionally able group of young men, many of whom have since become famous in industry and science. He inspired them with his energy, good judgment and boundless enthusiasm.

It was under O'Gorman that the long series of skilled researches on the safety of aircraft, which have set a standard to the world, was begun. It was at the Factory that the young Geoffrey de Havilland found the opportunity that led him to fame as a designer; it was there that E. T. Busk studied the stability of aircraft, and designed and flew, without touching the controls, the first stable aircraft in September 1913. It was at the Factory, too, that a young Cambridge physiologist, Keith Lucas, revolutionized compass design, at a time when the vagaries in eloud of the flat compass of naval design were attributed to mysterious magnetic forces. I only mention a few of the revolutions in the science of aeronauties the origin of which can be traced back to the work of the Royal Aircraft Factory in O'Gorman's time.

After Haldane left the War Office, O'Gorman had no firm Ministerial backing. Criticisms of the Factory mounted. O'Gorman was accused of competing unfairly with private aircraft firms. There was no truth in this; all the results of experimental work were communicated freely to industry. The design of experimental aircraft, at that time, was a necessary final test of the soundness of conclusions reached by research. The Factory was not a factory in the real sense of the word; it was, as it now is, an experimental establishment. Thousands of the machines designed at the Factory were constructed by outside firms. But a fierce attack, made in the House of Commons in 1916, led to the appointment of a Committee of Inquiry. The Committee recommended that the Factory should cease to engage in the production even of prototype experimental aircraft, and that O'Gorman's appointment, which was originally for a term of seven years, should not be renewed. $\mathrm{He}$ was made consulting engineer to the DirectorGeneral of Military Aeronautics, a position of no authority and of little influence. No wonder he felt bitter about his treatment. $\mathrm{He}$ made raistakes and enemies, of course, as anyone might, in his position, who tried to make anything. It is sad that he never received the public recognition that was his due.

After the War, O'Gorman did not return to private practice. He busied himself with a variety of voluntary work. $\mathrm{He}$ retained his remarkable physical and mental energy to an advanced age. $\mathrm{He}$ was always interesting and interested, especially in the doings of his 'young men'. He had a marked artistic talent. $\mathrm{He}$ loved making lacquer, and engraving. He lived for some sixty years in the house which he had bought when he married Florence Catharine Rasch in 1897. She died in 1931. They had no children, so there is no one to follow him. But he will always be remembered with affection by the friends who knew him well, and worked with him.

H. T. TIZARD

\section{Dr. Maxwell Garnett}

Dr. Maxwell Garnetr, principal of the College of Technology, Manchester, during 1912-20, and secretary of the League of Nations Union during 1920-38, died at Seaview, Isle of Wight, on March 19 at the age of seventy-seven.

James Clerk Maxwell Garnett was born at Cam. bridge in 1880, the son of William Garnett, who had been a colleague of James Clerk Maxwell. Maxwell Garnett was educated at St. Paul's School and Trinity College, Cambridge, where he was a major scholar, Smith's prizeman and Sheepshanks exhibitioner. He was placed in the first class of Division 1 of the 
Mathematical Tripos, Part II, and in 1905 was elected a Fellow of Trinity. In 1903 he was lecturer in applied mathematics at University College, London, and during 1904-12 was examiner to the Board of Education. In 1912 he became principal of the College of Technology, Manchester (then called the Municipal School). On resigning from this post in 1920, he was appointed secretary of the League of Nations Union, which he served until 1938.

Maxwell Garnett was a big man. Well over $6 \mathrm{ft}$. in height and built in proportion, he was endowed with great natural gifts of body and mind, which enabled him to row in the University trial eights at Cambridge, and at the same time to gain some of the highest mathematical honours. His early original papers on "The Colours in Metal Glasses and in Metallic Films", published in the Philosophical Transactions of the Royal Society, amply show the qualities of mind of the authentic mathematical physicistmathematical power and physical insight ; these had been combined, as he said himself, with a happy flash of inspiration which came to him as he was examining some coloured wine glasses on a dining table. The wide range of his interests is indicated by these early scientific papers and his many other publications on psychology and education, particularly "Education and World Citizenship", an essay towards a science of education, a great work of 515 pages published in 1921. He used to say that much of his hard thinking while he was with the Board of Education was done while travelling to and fro on the underground railway. During 1941-44 he was chairman of the British Association Committee on Post-War University Education; its report was prefaced by Sir Richard Gregory, then president of the Association.

His excess of physical energy he worked off through his love of the mountains and the sea. A visitor to his home at Seaview was in no danger of being allowed to relax. As the steamer neared the pier, instead of the normal disembarkation he would see approaching, powerfully stroked by Garnett, a Canadian canoe into which he would be invited to lower his person and luggage, to be whisked away to a small landing stage near Garnett's house ; and early the following morning he would be expected to join his host for a swim. In his Manchester days, with the mountains and sea far away, Garnett was often to be seen before breakfast running around Victoria Park with the zest of a man training for a race. Such indeed he was, training his great abilities, guided and controlled by high Christian principles, to serve the cause of education and the human race.

He had many of the qualities of the great leader. No one who worked with him could fail to admire the zeal and devotion with which he applied himself to the task in hand, or fail to gain something positive from his example. If he appeared somewhat intolerant to a few who could not see so far ahead or keep up the pace he set, this could perhaps be explained by his own modesty, which would not allow him to admit that the energy and foresight of others might fall short of his own.

His high principles caused him to resign his principalship in 1920 when he did not see eye to eye with the Manchester Education Committee, which had decided to confine the university side of the College of Technology within limits which Garnett regarded as too narrow to meet the coming needs of the country for trained technologists. An example of his forward-looking qualities was his appointment of Murray Wrong, of Oxford, as vice- principal to help "to civilize the technical students". In recent years he no doubt followed with pleasure the rapid extensions that have been taking place and plans for further extensions. These were foreseen during his period of office, for the Manchester Guardian pointed out that "Mr. Garnett in addition to the ordinary labours of post-war reconstruction, had been the chief instrument in the collection of some $£ 130,000$ " intended to further the growth of the College.

Again, in 1938, having devoted all his powers to the ideals of the League of Nations Union, his principles compelled him to resign the secretaryship when he feared that the Union might be "used as an instrument of political propaganda".

Garnett was very happily married to Margaret Lucy, gifted, generous and warm-hearted, the second daughter of Sir Edward Poulton; she, three daughters and three sons, survive him. F. Bowman

\section{Mr. O. T. Faulkner, C.M.G.}

OdIN FAULKNER's career was one of great promise, fine achievement and deep disappointment. He distinguished himself at St. Albans School by gaining the Hertfordshire County Agricultural Scholarship and a major scholarship to Caius College, Cambridge. $\mathrm{H}_{\Theta}$ had a brilliant university career, graduating with first-class honours in the Natural Science Tripos in 1911 and obtaining the diploma in agriculture in 1912.

After two years with the Rubber Growers' Association, Malaya, he joined the Indian Agricultural Service as deputy director of agriculture, Lyallpur, Punjab.

In 1921, at the early age of thirty, he was appointed to the important post of Director of Agriculture in Nigeria, and it was in that country that he achieved fame. He clearly saw that the traditional system of shifting cultivation could not long sustain an increasing population, and observed that soil fertility had fallen to a dangerously low level in large sections of the country. He concentrated the efforts of his Department on devising means of maintaining soil fertility under permanent systems of cultivation. $\mathrm{He}_{\boldsymbol{\theta}}$ created consternation in Government circles by demanding a breathing space of ten years in which to solve this major problem. He inspired his staff with his own enthusiasm, and by patient team-work they evolved a system of mixed farming for the Northern Province and green manuring for the Southern Province.

He accepted transfer to Malaya in 1936, with some reluctance, but welcomed his appointment to the post of principal of the Imperial College of Tropical Agriculture in the West Indies in 1938. Here, he felt, was a challenge worthy of his mettle. The forthcoming visit of the West India Royal Commission appeared to offer a unique opportunity of enabling the College to fulfil its real destiny. In close collaboration with his collesgues, he drew up a long-term programme of development. The outbreak of war, in 1939, deferred indefinitely the implementation of this programme, and denied him what would have been the crowning achievement of his career.

Although Faulkner carried out his duties with efficiency and led the staff in numerous voluntary activities in furtherance of the war effort, his work had lost its savour. He retired in 1946 and spent his first winter in England helping to build the yacht, Chantek, which became the home of the 